\title{
STUDI KEBIJAKAN, PERENCANAAN DAN PELAKSANAAN KESELAMATAN DAN KESEHATAN KERJA RUMAH SAKIT (K3RS) DI RUMAH SAKIT UMUM (RSU) MITRA SEJATI MEDAN TAHUN 2018
}

\author{
Hana Ike Dameria Purba ${ }^{*}$, Vierto Irennius Girsang ${ }^{1}$, Ulfa Syahriani Malay ${ }^{1}$ \\ 1Program Studi Kesehatan Masyarakat, Fakultas Farmasi dan Ilmu Kesehatan Universitas \\ Sari Mutiara Indonesia, Gedung B Lantai 1 Jl. Kapten Muslim No. 79 Medan 20123, \\ Indonesia
}

*Penulis Korespondensi: Hana Ike Dameria Purba,Program Studi Kesehatan Masyarakat, Fakultas Farmasi dan Ilmu Kesehatan Universitas Sari Mutiara Indonesia, Gedung B Lantai 1 Jl. Kapten Muslim No. 79 Medan 20123, Indonesia, E-mail: purbahana@yahoo.com/ hanapurba29@gmail.com, Phone: +6281397850898, Fax: -

\begin{abstract}
ABSTRAK
Rumah sakit sebagai industri jasa yang mempunyai beragam persoalan tenaga kerja yang rumit dengan berbagai risiko terkena penyakit akibat kerja bahkan kecelakaan akibat kerja sesuai jenis pekerjaannya, sehingga berkewajiban menerapkan upaya Keselamatan dan Kesehatan Kerja Rumah Sakit (K3RS). Namun, fenomena banyak ditemukan bahwa kebijakan, perencanaan serta pelaksanaan K3RS tampaknya belum terlaksana secara maksimal sesuai standar, sehingga pekerja rumah sakit banyak mengalami masalah kesehatan dan keselamatan kerja. Penelitian ini bertujuan untuk mengetahui kebijakan, perencanaan dan pelaksanaan K3RS yang dilaksanakan di RSU Mitra Sejati Medan. Jenis penelitian yang digunakan pada penelitian ini adalah kualitatif dengan tujuan untuk mendapatkan informasi mendalam tentang penerapan kebijakan, perencanaan dan pelaksanaan K3RS. Data primer diperoleh dengan triagulasi teknik pengumpulan data; wawancara mendalam, observasi dan dokumentasi. Informan pada penelitian ini ada tiga informan yang kompeten perwakilan masing-masing instalasi yakni ketua K3RS, pegawai instalasi kesling dan instalasi keperawatan. Hasil penelitian menunjukkan bahwa RSU Mitra Sejati Medan telah menerapkan sistem manajemen kesehatan dan keselamatan kerja rumah sakit. Dimana RS telah membuat kebijakan dan perencanaan K3RS akan tetapi pelaksanaan K3RS hanya terlaksana 11 kegiatan dari 25 kegiatan. Rekomendasi untuk pihak Rumah Sakit (RS) untuk meningkatkan pelaksanaan K3RS dari segala pihak yang terlibat di rumah sakit Mitra Sejati, sehingga penerapannya bukan hanya program saja melainkan sebagai budaya K3 di rumah sakit dalam meningkatkan derajat kesehatan pekerja.
\end{abstract}

Kata Kunci : Kebijakan, Perencanaan, Pelaksanaan, K3RS 


\section{PENDAHULUAN}

Standar Kesehatan dan Keselamatan Kerja di RS (K3RS) perlu ditetapkan untuk mencegah dan mengurangi risiko kecelakaan dan penyakit akibat kerja di RS.Demi terciptanya jaminan keselamatan kerja maka diperlukan pelayanan strategis yang profesional serta prosedur kerja yang tetap, tidak hanya tergantung pada peraturan-peraturan yang mengayominya dan finansial yang diberikan, melainkan banyak faktor yang harus ikut terlibat, diantaranya adalah pelaksanaan organisasi.Suatu organisasi yang berhasil dapat diukur dengan melihat pada sejauh mana organisasi tersebut dapat mencapai tujuannya.Pelaksanaan K3 di RS dapat dinilai dari kefektivitasan organisasi K3 tersebut (Kun dwi apriliawati,2017).

Berdasarkan data dari World Health Organization (WHO) : Dari 35 juta pekerja kesehatan 3 juta terpajan patogen darah (2 juta terpajan virus HBV, 0,9 juta terpajan virus HBC dan 170,000 terpajan virus HIV/ AIDS). Dapat terjadi : 15,000 HBC, 70,000 HBB \& 1000 kasus HIV. Lebih dari 90\% terjadi di negara berkembang.8-12\% pekerja rumah sakit, sensitif terhadap lateks. Probabilitas penularan HIV setelah luka tusuk jarum suntik yang terkontaminasi HIV 4: 1000. Risiko penularan HBV setelah luka tusuk jarum suntik yang terkontaminasi HBV 27-37: 100. Risiko penularan HCV setelah luka tusuk jarum suntik yang mengandung HCV 3 - 10 : 100 (Sunandar, 2017).

Rumah Sakit Umum Mitra Sejati sebagai salah satu pusat rujukan pelayanan kesehatan berusaha memberikan pelayanan menyeluruh dibidang kesehatan secara cermat dan tepat.Dengan didukung tenaga medis yang profesional dan berkompeten dibidangnya, serta sarana dan prasarana yang modern dan lengkap dengan tarif yang terjangkau oleh masyarakat pada umumnya.Dengan memegang teguh pada prinsip sosial, Rumah Sakit Umum Mitra Sejati secara terus menerus meningkatkan pelayanan kesehatan yang terbaik kepada masyarakat dan aktif berperan serta membantu pemerintah dalam upaya meningkatkan derajat kesehatan masyarakat.

Menurut survei awal, ditemukan bahwa K3RS di RSU Mitra Sejati Medan sudah berjalan sekitar 5 tahun. Pada tahun 2018, diketahui bahwa berdasarkan data kecelakaan kerja di RSU Mitra Sejati Medan adalah sebanyak 6 oranguntuk kasus tertentu yaitu pada bulan Januari yang terkena jarum suntik sebanyak 1 (satu) orang, sedangkan pada bulan Februari sampai dengan Mei tidak ada terjadi kecelakaan kerja, pada bulan Juni terjadi kembali kecelakaan kerja sebanyak 2 (dua) orang, 1 orang terkena jarum suntik dan 1 orang terkena nald hecting, untuk bulan Juli sampai September tidak ada terjadi kecelakaan kerja. Menurut 
data tersebut dapat diketahui bahwa kondisi penerapan studi K3RS berdasarkan survei awal masih belum menunjukkan kondisi yang optimal.Dalam hal ini, kasus yang terjadi akibat kelalaian pekerja di RSU Mitra Sejati Medan.Oleh karena itu, sangat diperlukan studi kebijakan, perencanaan dan pelaksanaan K3RS di RSU Mitra Sejati Medan, maka dari hasil tersebut sangat diperlukan pengawasan terhadap K3RS.Tujuan Umum penelitian ini adalah untuk mengetahui kebijakan, perencanaan dan pelaksanaan K3RS yang dilaksanakan di RSU Mitra Sejati Medan.

\section{METODE PENELITIAN}

Jenis penelitian ini merupakan penelitian kualitatif untuk menggambarkan bagaimana studi kebijakan, perencanaan dan pelaksanaan Keselamatan dan Kesehatan Kerja (K3RS) di RSU Mitra Sejati tahun 2018. Informan penelitian adalah pihak-pihak yang memiliki wewenang dan/atau pengetahuan mengenai kebijakan, perencanaan dan pelaksanaan Keselamatan dan kesehatan kerjaRumah Sakit (K3RS)sebanyak 3 orang yaitukepala bagian K3RS, dankepala instalasi kesehatan lingkungan, sertasalah satu bagian keperawatan untuk mengetahui proses pelaksanaan K3 di rumah sakit tersebut.Data Primer diperoleh dari Metode Wawancara, observasi dan dokumentasi. Metode wawancara yakni dengan menggunakan alat bantu berupa perekam digital dan handphone. Wawancara dilakukan dengan 3 orang informan.Metode Observasi yakni dengan Teknik pengumpulan dan pengambilan data dengan pengamatan serta survei langsung ke lapangan dan pengamatan langsung terhadap aktivitas kerja pekerja RSU Mitra Sejati mengenai kebijkan, perencanaan dan pelaksanaan K3RS.Penelitian ini juga melakukan pengamatan langsung dengan menggunakan daftar checklist, dan dengan Studi dokumentasi yaitu dengan mengamati setiap dokumen-dokumen mengenai kebijakan, perencanaan dan pelaksanaan K3RS yang ada di RSU Mitra Sejati Medan.Adapun variabel dalam penelitian ini yakni penetapan kebijakan, perencanaan K3RS, dan pelaksanaan K3RS. Instrumen yang dipakai untuk pengumpulan data adalah peneliti sendiri.Analisa data dilakukan dengan tahapan transkript data, reduksi data penyajian data, triagulasi teknik, penyajian data dan penarikan kesimpulan

\section{HASIL}

\section{Kebijakan K3RS di RSU Mitra Sejati}

Berdasarkan hasil wawancara kebijakan dalam menjalankan K3RS ditetapkan oleh pimpinan rumah sakit dan dibuat secara tertulis, resmi dan mudah dipahami oleh seluruh SDM rumah sakit.RSU Mitra Sejati telah menerapkan kebijakan tersebut sesuai dengan 
peraturan Menteri Kesehatan dimana RS telah membuat kebijakan yang telah disusun dan diperiksa oleh direktur dan dibuat dalam bentuk tertulis.Rumah Sakit juga telah melibatkan organisasi didalam penetapan K3RS, sedangkan untuk mekanisme kerja sudah dibuat sesuai dengan struktural dan untuk pengalokasian anggaran dibuat dalam per 3 (tiga) bulan sekali dan dikoordinasikan kembali. Berikut petikan informan dengan kepala K3RS sebagai berikut : "pekerja itu semua harus dimanajemen sebaik mungkin untuk menghindari terjadinya resiko kecelakaan kerja. kita identifikasi dulu resiko apa aja yang mungkin terjadi, setelah kita ketahui resikonya kita greeding mana resiko yang harus kita selesaikan baru kita kendalikan resiko, pengendalian resiko itu ada 5 sampe apa itu penggunaan APD. pertamakan ada eliminasi, substitusi, rekayasa engineering, baru administrasi dan penggunaan APD. sebenarnya kebijakan disini semua fasilitas harus terjamin dapat menjadi keselamatan baik itu pasien, baik itu keluarga, baik itu pendamping pasien dan baik orang-orang yang berada dan staf di RS ini harus terjamin keselamatannya."

“... kebijakannya dari SK direktur” ... Tertulis”

“...setiap unit kerja atau komite disini pasti dikasih bukan hanya keperawatan jadi setiap unit juga akan dikasih kebijakan, pedoman, panduan. karna itu semuanya sudah masuk terakreditasi semua unit harus tau."

“...Organisasi yang terlibat itu paling spesifik kami fasilitas itu satu IPSRS (Instalasi Sarana Dan Prasarana Rumah Sakit) kalau untuk fasilitas. kalau untuk lingkungan itu ada bagian kesling. kalau masalah penyakit orang bagian PPI. tiga paling ... paling penting dalam penerapan K3 itu IPSRS fasilitas, kalau lingkungan ke orang .... “

“...Mekanisme kerjanya. eee... itu dari structural .... dari ketua komite K3RS itu diketuai oleh dokter langsung baru .. sekretaris K3RS itu lah yang memanajemen semua dan standart K3RS itu harus mempunyai pelatihan atau sertifikat tentang manajemen K3RS."

“...Prinsipnya koordinasi komunikasi dan kolaborasi. kalau masalah tugasnya kita punya jobnya sendiri kan setiap unit beda-beda jadi tergantung dari unitya sendiri. setiap unit harus bertanggungjawab kepada kepalanya..."

“...Anggaran itu kemarin, kita survei dulu ke lokasi mana fasilitas yang perlu diadakan dan yang paling perlu. gitu per tiga bulan dibuat anggarannya mana hal-hal yang beresiko."

“...biaya mereka yang berkoordinasikan dengan owner untuk pembiayaan.”

\section{Perencanaan K3RS di RSU Mitra Sejati}

Dari segi perencanaan K3RS, RSU Mitra Sejati telah membuat perencanaan K3RS dimana pihak K3RS telah menyiapkan beberapa hal untuk manajemen risiko yang telah ditetapkan oleh direktus RS. Berikut petikan informan dengan kepala K3RS sebagai berikut : 
"Perencanaannya (hening) perencanaan kita kemarin itu disiapkan beberapa hal seperti di manajemen risiko kita greding risiko satu lagi buat ee perencanaan setelah direncanakan baru buat pelaksanaan nya dan itu ditetapkan oleh direktur RS."

\section{Pelaksanaan K3RS di RSU Mitra Sejati}

Berdasarkan hasil wawancara pelaksanaan manajemen risiko di RStelah dilaksanakan oleh setiap unit / komite RS dan pihak RS juga membuat beberapa organisasi manajemen risiko.Berikut petikan wawancara manajemen risiko dengan ketiga informan :

“...Pelaksanaan, dikaji dulu manajemen risikonya setiap unit, misal diruangan penyimpanan B3 di farmasi itu beresiko terjadinya kebakaran, diruang penyimpanan MTG itu berisiko, diruang ee ..isolasi itu terjadi penularan penyakit jadikan kita kaji semua risiko-risiko apa aja yang mungkin terjadi dan kalau orang datang kesitu sangat berbahaya dan memenuhi prosedur."

"...Manajemen risikonya hampir sama dengan K3."

“...Untuk B3 nya juga, istilahnya untuk limbah cair kita filtrasi sesuai persyaratan sanitasi di RS itu."

".... pelaksanaan manajemen risiko sudah berjalan, nah untuk manajemen risiko itu sendiri kita ada bentuk beberapa organisasi atau komite salah satunya komite MFK (Manajemen Fasilitas Keamanan) terus juga ada PMKP untuk mutunya IPCN nya sendiri terkait dengan kinerja dari K3. jadi jika ada kejadian-kejadian beresiko tentang manajemen risiko itu selalu terkait antara PPI dengan ee ... MFK K3 itu sendiri.”

Pelaksanaan keselamatan dan keamanan di RS juga telah dilaksanakan oleh setiap unit/komite RS dan pihak RS juga memfasilitasi alat pelindung untuk tiap pekerja. Berikut petikan wawancara keselamatan dan keamanan RS :

“.... kegiatan yang bersifat infeksi dia menggunakan APD menyuntik, membersihkan luka, handskun masker dapat, terus untuk dikesling kalau masuk pengolahan limbah menggunakan APD lengkap seperti masker,masker N95 baru sepatu both, baju khusus setelah selesai pekerjaannya baju disterilkan."

Dari segi pelaksanaan pelayanan kesehatan kerja di RS ditemukan bahwa pelayanan

kesehatan kerja telah dilaksanakan oleh pihak RS untuk melindungi sumber daya manusia yang berada di RS. Berikut petikan wawancara pelayanan kesehatan kerja RS :

“... masih kita program kan yaitu untuk karyawan sebelum masuk bekerja harus diperiksa terlebih dahulu dan pekerja yang sudah bekerja disini melakukan pemeriksaan rutin dan orang-orang yang mempunyai penyakit dan telah diperiksa mempunyai penyakit khusus maka dilakukan pemulihan.

“"... sudah bekerja sama dengan BPJS ketenagakerjaan jadikan kalau biaya untuk kecelakaan PAK itukan ditanggung ketenagakerjaan."

“...Kalau disini kitakan dapat bimbingan dari K3 pengadaan APD. apa namanya .. kayak APD gitu, contohnya kayak diberi masker. kita kontak dengan limbah B3..”

“...pelayanan kesehatan kerja misalnya ada klain kita yang mengalami kecelakaan di jam kerja kita biasanya melindungi mereka dengan menggunakan BPJS ketenagakerjaan. jadi segala sesuatu yang terjadi sama karyawan kalau misalnya ada 
terkena risiko cidera saatproses kerja mereka kita layanin dengan difasilitasi BPJS ketenagakerjaan."

Terkait dengan pelaksanaan pengelolaan B3 diketahui bahwa pengelolaan B3 telah dilaksanakan oleh pihak RS sesuai dengan yang direncanakan terlebih dahulu. Berikut petikan wawancara dengan informan :

“... pengelolaannya kan pertama itukan kita harus ada perencanaan pengadaan B3 ..."

“... direncanakan waktu periode selama sebulan.”

“... pengadaan, pendistribusian. pengadaan disimpan ditempat penyimpanannya baru didistribusikan sesuai permintaan dari luar."

“... untuk mengurangi limbahnya kita menggunakan pemakaian daur ulang, misal minta alcohol dia pake botol nanti kalau abis isinya ambil lagi gitu, jadikan tidak mengurangi ongkos untuk pembiayaan pemusnahan limbah."

“... pengelolaan B3 nya sendiri kita juga melakukan pengelolaan berkerja sama dengan K3nya."

“...Kalau untuk kesling mulai dari bahan beracun. intinya semua bahan B3 itu memiliki MSDS...”

Berdasarkan hasil wawancara mengenai pencegahan dan pengendalian kebakaran telah dilaksanakan oleh pihak RS sesuai dengan yang direncanakan terlebih dahulu. Berikut petikan wawancara dengan informan :

“...menyediakan sarana dan prasarana jika terjadi kebakaran untuk pengendaliannya, misal kan ada kalau dalam kebakaran proteksi aktif dan pasif kalau pasif itu berkaitan dengan bahan api itu perencanaan awal..."

“... proteksi aktif kita perbanyak bisa nanti ada sprinkler ada smoke detector, ada $A P A R$, ada hydrant itu namanya kita rencanakan semua dilingkungan RS kita sudah siap. itulah pengendalian kebakaran..."

“...penanggulangan jika terjadi kebakaran, misal petugas pake topi ada merah, kuning, putih, biru jadi semua punya peran masing-masing. Petugasnya masing-masing itu dilatih kayakmana kalau terjadi kebakaran..."

“...pertama kita latih cara penggunaan APAR, cara memadamkan api menggunakan penutup air dengan cara menggunakan pasir. hal-hal pemadaman api itukan gas tidak boleh dipadamkan dengan air harus dengan CO2, APAR..."

“...dilakukan pelatihan, kayak evakuasi bencana kebakaran..”

“...Semua karyawan dikasih pelatihan semua bukan hanya keperawatan aja.”

Berdasarkan hasil wawancara mengenai pelaksanaan pengelolaan prasarana RS belum begitu terlaksana karena ada beberapa peralatan medis yang belum tersedia seperti diruang infeksi yang memerlukan masker khusus. Berikut petikan wawancara dengan informan :

“...Kalau prasaran itu tadi saya bilang programnya IPSRS mereka mengelola semua...prasarana itukan ada yang tahunan seperti pengecetan, kalau misalnya kayak 
air. kalau gedung melakukan pemeriksaan retakan-retakan atau hal yang dapat mencelakain. semuanya itu dilakukan instalasi sarana dan prasarana."

“...prasarana untuk air jika listrik mati dari PDAM alternatifnya kita ada sumur bor, kalau untuk listrik kita gunakan PLN jika lampu mati sediakan genset 24 jam ...”

“...Kalau dibilang lengkap sih enggak begitu lengkap kali cuman kita sejauh ini udah melengkapi beberapa peralatan yang sangatt dibutuhkan untuk melengkapi sarana prasarana yang dibutuhkan nanti.."

“...dilakukan oleh orang maintance kolaborasi dengan orang K3 kita."

Berdasarkan hasil wawancara mengenai pelaksanaan pengelolaan peralatan medis telah dilaksanakan oleh pihak RS sesuai dengan yang direncanakan terlebih dahulu. Berikut petikan wawancara dengan informan :

“...dilakukan pemeliharaan sekali sebulan dan untuk alat-alat mesin atau yang menghasilkan ukuran seperti sharingpumb harus dikalibrasi sekali setahun. instrument medis dilakukan sterilisasi diruang CCSD.."

“...Biasanya kita koordinasi dengan orang logistic dengan orang maintance jadi kita biasanya minta alat medis kita buat surat kira-kira alatnya udah perlu untuk dikalibrasi atau tidak layak dipakai lagi kita buat surat ke bagian maintance mentindaklanjut lalu berkoordinasi dengan orang logistic pengadaan mereka yang mentindaklanjutin nanti.."

Hasil Pengambilan Data Berdasarkan Daftar Periksa (Check List)

Tabel 4.2

DAFTAR PERIKSA (CHECK LIST)

STUDI KEBIJAKAN, PERENCANAAN DAN PELAKSANAAN KESELAMATAN DAN KESEHATAN

KERJA RUMAH SAKIT (K3RS) DI RUMAH SAKIT UMUM (RSU) MITRA SEJATI MEDAN TAHUN 2018

\begin{tabular}{|l|l|l|l|}
\hline \multirow{2}{*}{ No } & \multicolumn{1}{|c|}{ Uraian } & \multicolumn{1}{|c|}{ Pemenuhan } \\
\cline { 3 - 4 } & \multicolumn{1}{|c|}{ Ya } & Tidak \\
\hline 1. & Apakah Rumah Sakit memiliki organisasi K3? & $\checkmark$ & \\
\hline 2. & $\begin{array}{l}\text { Apa program kerja K3RS direvisi kembali sesuai dengan } \\
\text { kebutuhan? }\end{array}$ & $\checkmark$ & \\
\hline 3. & $\begin{array}{l}\text { Apakah pihak RS mendiskusikan K3 kepada seluruh SDM RS baik } \\
\text { itu pasien maupun pengunjung RS? }\end{array}$ & & $\checkmark$ \\
\hline 4. & $\begin{array}{l}\text { Apa promosi K3 dilakukan oleh pekerja disetiap unit RS dan para } \\
\text { pasien maupun pengunjung RS? }\end{array}$ & & $\checkmark$ \\
\hline 5. & $\begin{array}{l}\text { Apa RS memiliki rambu-rambu yang menyangkut keselamatan dan } \\
\text { keamanan RS? }\end{array}$ & $\checkmark$ & \\
\hline 6. & Apa RS menyediakan APD sesuai dengan SOP? & $\checkmark$ & \\
\hline 7. & $\begin{array}{l}\text { Apakah pekerja mendapatkan pemeriksaan kesehatan secara } \\
\text { berkala? }\end{array}$ & & $\checkmark$ \\
\hline 8. & $\begin{array}{l}\text { Apakah pihak RS memberikan pengobatan dan perawatan serta } \\
\text { rehabilitasi bagi SDM RS yang menderita sakit? }\end{array}$ & & $\checkmark$ \\
\hline 9. & Apakah RS melaksanakan kegiatan surveilans kesehatan kerja? & & $\checkmark$ \\
\hline 10. & Apakah pihak RS memberikan imunisasi pada SDM RS yang & $\checkmark$ & \\
\hline
\end{tabular}




\begin{tabular}{|c|c|c|c|}
\hline & bekerja diarea yang risiko bahaya tinggi? & & \\
\hline 11. & $\begin{array}{l}\text { Apakah pihak RS melakukan pengawasan keselamatan/ keamanan } \\
\text { sarana prasarana? }\end{array}$ & $\checkmark$ & \\
\hline 12. & $\begin{array}{l}\text { Apakah pekerja mendapatkan tanda pengenal sementara diarea } \\
\text { berisiko tinggi? }\end{array}$ & $\checkmark$ & \\
\hline 13. & $\begin{array}{l}\text { Apakah pihak RS melakukan pengecekan perlengkapan } \\
\text { keselamatan kerja di RS? }\end{array}$ & $\checkmark$ & \\
\hline 14. & $\begin{array}{l}\text { Apakah RS melaksanakan program return to work bagi SDM RS } \\
\text { yang mengalami PAK? }\end{array}$ & & $\checkmark$ \\
\hline 15. & Apakah pihak RS melakukan sistim shif kerja? & $\checkmark$ & \\
\hline 16. & $\begin{array}{l}\text { Apa RS menyediakan Lembar data keselamatan bahan (MSDS) } \\
\text { yang terkait prosedur penanganan aman? }\end{array}$ & & $\checkmark$ \\
\hline 17. & Apa RS membuat sarana keselamatan B3? & & $\checkmark$ \\
\hline 18. & Apakah RS memiliki pengelolaan limbah B3 sendiri? & $\checkmark$ & \\
\hline 19. & Apakah Pengelolaan B3 diterapkan sesuai dengan SOP? & & $\checkmark$ \\
\hline 20. & Apakah dilakukan pelatihan mengenai B3? & & $\checkmark$ \\
\hline 21. & $\begin{array}{l}\text { Apakah pelatihan pengendalian kebakaran dilakukan oleh seluruh } \\
\text { pekerja? }\end{array}$ & & $\checkmark$ \\
\hline 22. & $\begin{array}{l}\text { Apakah tersedia APAR, deteksi asap dan api, sistim alarm } \\
\text { kebakaran, penyemprotan air otomatis, pintu darurat, jalur evakuasi, } \\
\text { tangga darurat, pengendalian asap, hydrant? }\end{array}$ & $\checkmark$ & \\
\hline 23. & $\begin{array}{l}\text { Apakah pihak RS membentuk rencana penyusunan organisasi } \\
\text { tanggap darurat? }\end{array}$ & & $\checkmark$ \\
\hline 24. & $\begin{array}{l}\text { Apakah dilakukan pelatihan dan uji coba tanggap darurat terhadap } \\
\text { petugas? }\end{array}$ & & $\checkmark$ \\
\hline 25. & $\begin{array}{l}\text { Apakah dibentuk sistem komunikasi internal dan eksternal tanggap } \\
\text { darurat RS? }\end{array}$ & & $\checkmark$ \\
\hline
\end{tabular}

(Republik Indonesia Permenkes No. 66, 2016)

Dari hasil pengambilan data diatas melalui lembar check list pada Permenkes No. 66 tahun 2016, tentang keselamatan dan kesehatan kerja rumah sakit (K3RS), maka pelaksanaan pencapaian penerapan yang dilaksanakan di RSU Mitra Sejati Medan hanya sebanyak 11 kegiatan yang telah dilaksanakan.

\section{PEMBAHASAN}

\section{Kebijakan K3RS di RSU Mitra Sejati Medan}

Kebijakan rumah sakit Mitra Sejati Medan dalam menerapkan sistem manajemen K3RS dalam bentuk surat kerja yang telah disusun dan diperiksa oleh direktur dan dibuat dalam bentuk tertulis yang diwujudkan dalam bentuk struktural organisasi tim K3RS yang memiliki tugas dan fungsi masing - masing. Pelaksanaan kesehatan dan keselamatan kerja rumah sakit tidak akan berjalan dengan baik jika direktur rumah sakit tidak menetapkan kebijakan untuk seluruh sumber daya rumah sakit. Untuk pengalokasian pendanaan telah dibuat sesuai dengan peningkatan sumber daya manusia dengan keahlian dibidang masing - 
masing dan pihak RS juga membuat pengalokasian pendanaan sesuai dengan pelaksanaan program K3 serta didalam pengalokasian anggaran dibuat dalam per 3 (tiga) bulan sekali dan dikoordinasikan kembali. Sebab suatu program K3 tidak akan terlaksanakan jika tanpa adanya pengalokasian pendanaan.

Kebijakan K3 telah ditetapkan dan masih dalam proses perbaikan yang lebih baik lagi untuk mewujudkan sarana dan prasarana serta SDM yang lebih baik untuk melaksanakan K3. Namun, diakui bahwa sarana dan prasarana yang tersedia masih minim, misalnya untuk APD diruang tertentu belum sesuai dengan standart yang telah ditetapkan karena membutuhkan biaya yang sangat besar.

Semua anggota yang ada di struktur organisasi Komite Keselamatan dan Kesehatan Kerja RS terlibat didalam perencanaan kebijakan K3 dalam bentuk sumber daya yang berupa karyawan mendapatkan pelatihan K3. Peninjauan ulang kebijakan K3 akan dicapai dalam setiap tahun, berdasarkan data yang diperoleh bahwa penerapan kebijakan K3 di RSU Mitra Sejati Medan sudah terlaksana sesuai dengan Permenkes No. 66 Tahun 2016.

Kebijakan K3 ini sejalan dengan penelitian Sunandar (2017), dimana RS telah menetapkan kebijakan K3 secara tertulis terkait pelaksanaan Keselamatan dan Kesehatan Kerja (K3) yang ditanda tangani langsung oleh direktur. Kebijakan tersebut bersifat top down maksudnya pimpinan RS telah memiliki standar pelayanan K3 di Rumah Sakit, kemudian diadopsi dan disesuaikan dengan kondisi Rumah Sakit. Kebijakan tersebut di rumuskan oleh timK3RS dan melakukan konsultasi dengan pihak pihak yang terkait, kemudian di usulkan ke direktur dan ditandatangani. Kebijakan tersebut ditembuskan keseluruh unit/pokja terkait, dikomunikasikan dalam bentuk sosialisasi atau kegiatan simulasi.Pihak K3RS juga melakukan tinjauan ulang kebijakan secara berkala untuk menyesuaikan kebijakan Keselamatan dan Kesehatan Kerja yang diterapkan Rumah Sakit dengan perkembangan kondisi Rumah Sakit dan perubahan peraturan perundang-undangan.

\section{Perencanaan K3RS di RSU Mitra Sejati Medan}

Perencanaan K3RS dilakukan untuk menghasilkan perencanaan strategi K3RS, yang diselaraskan dengan lingkup manajemen Rumah Sakit.Perencanaan K3RS tersebut disusun dan ditetapkan oleh pimpinan Rumah Sakit dengan mengacu pada kebijakan pelaksanaan K3RS yang telah ditetapkan dan selanjutnya diterapkan dalam rangka mengendalikan potensi bahaya dan risiko K3RS yang telah teridentifikasi dan berhubungan dengan operasional Rumah Sakit. Dalam rangka perencanaan K3RS perlu mempertimbangkan peraturan 
perundang-undangan, kondisi yang ada serta hasil identifikasi potensi bahaya keselamatan dan Kesehatan Kerja (Republik Indonesia Permenkes No. 66, 2016).

Dalam perencanaan keselamatan dan kesehatan kerja rumah sakit Mitra Sejati melakukan suatu program tentang pedoman keselamatan dan kesehatan kerja rumah sakit di rumah sakit Mitra Sejati Medan. Perencanaan - perencanaan program yang dilaksanakan sudah ada ditetapkan dan memiliki pedoman dalam penanggulangan keselamatan dan kesehatan kerja di rumah sakit.Dalam perencanaan keselamatan dan kesehatan kerja rumah sakit tersebut sudah membuat pencapaian SMK3 RS, dimana untuk mencapai sasaran pihak rumah sakit telah membuat suatu laporan pencatatannya masing - masing dari tiap unit di rumah sakit.

Perencanaan K3RS di RSU Mitra Sejati Medan sejalan dengan penelitian Firman (2010), bahwa perencanaan K3 dilaksanakan dengan melakukan analisa awal dan menentukan proritas masalah. Sementara sebagian lainnya menjawab bahwa suatu perencanaan dilaksanakan berdasarkan kesiapan perlengkapan yang ada, karena didalam perencanaan K3 pelatihan dilakukan jika perlengkapan sudah ada sehingga program yang telah ditetapkan akan terlaksanakan. Program K3 dilaksanakan dengan mempertimbangkan tingkat resiko dan tindakan upaya pencegahan. Sedangkan pada penelitian Salmawati (2015) bahwa program SMK3 diterapkan oleh P2K3 yang sudah cukup menitikberatkan pencegahan penyakit dan kecelakaan kerja serta pada tindakan atau respon kegawatdaruratan seperti pembuatan rambu-rambu K3, melakukan penelitian keadaan darurat misalnya kecelakaan. Namun pada faktor fisik lingkungan kerja di RS tersebut belum teratasi dengan baik seperti pembuangan sampah.Selain itu program-program K3 di RS tersebut telah membuat kegiatan yang dapat meningkatkan motivasi kerja seperti dengan mengadakan lomba antar ruangan, serta rekreasi bersama namun belum terjadwalkan dengan baik.

\section{Pelaksanaan K3RS di RSU Mitra Sejati Medan}

Dalam pelaksanaan keselamatan dan kesehatan kerja rumah sakit bahwa rumah sakit telah melaksanakan program yang telah ditetapkan sesuai dengan panduan sistem pencatatan dan pelaporan insiden keselamatan yang dimiliki oleh pihak rumah sakit.Pihak rumah sakit juga sudah melaksanakan program kerja proaktif berupa identifikasi dan meminimalkan insiden keselamatan di rumah sakit. Semua insiden yang terjadi di rumah sakit harus dilaporkan secara tertulis dalam waktu maksimal 2 × 24 jam dengan diketahui direktur rumah sakit langsung. Maka hasil insiden tersebut ditindak lanjuti dan ditentukan berdasarkan grading risiko yaitu berupa investigasi sederhana yang dilakukan oleh unit masing - 
masing.Dan hasilnya dilaporkan kepada komite atau unit yang terkait.Faktor yang mempengaruhi telaksanakan K3RS di rumah sakit Mitra Sejati adalah pihak sumber daya manusia RS yang telah diberikan pelatihan yang mendukung terlaksananya K3RS.Rumah Sakit Mitra Sejati juga akan berfokus pada meningkatkan sumber daya manusia dalam pelatihan dibidang - bidang keselamatan kerja agar dapat lebih meminimalisirkan angka kecelakaan akibat kerja dan penyakit akibat kerja.

Pelaksanaan K3RS di RSU Mitra Sejati Medan sejalan dengan penelitian Nurpitriani (2013) bahwa pelaksanaan K3 masih berkisar 50 - 60 persen dari program pelaksanaan K3 yang telah ditetapkan di rumah sakit, sebab aspek K3 di rumah sakit sangat beragam yang menyangkut keselamatan tenaga medis, pasien, pekerja, pengunjung dan masyarakat sekitarnya.Sedangkan pada penelitian Sunandar (2017) bahwa RS telah melakukan pelayanan keselamatan dan kesehatan kerja dengan baik. Pihak Rumah Sakit juga telah melakukan kegiatan pemeriksaan kesehatan terhadap pegawainya, pemeriksaan tersebut dilakukan sebelum petugas masuk, pemeriksaan setiap enam bulan, pemerikasaan khusus, dan pemerikassan paripurna, tetapi proses pencatatan dan pendataan belum dilaksanakan dengan baik. Rumah Sakit juga melakukan vaksinasi terhadap karyawan secara berkala.

\section{KESIMPULAN}

Rumah Sakittelah menerapkan kebijakan sistem manajemen keselamatan dan kesehatan kerja rumah sakit (SMK3 RS), dimana Rumah Sakit Mitra Sejati Medan telah membuat kebijakan K3RS berupa surat keputusan yang ditetapkan oleh direktur rumah sakit dan dibuat secara resmi dan tertulis.Proses perencanaan K3RS di RS Mitra Sejati Medan telah mengacu pada kebijakan pelaksanaan keselamatan dan kesehatan kerja, dimana perencanaan program yang dilaksanakan sudah ada ditetapkan dan memiliki pedoman dalam penanggulangan keselamatan dan kesehatan kerja di rumah sakit.Pelaksanaan keselamatan dan kesehatan kerja rumah sakit disini telah disusun berdasarkan rencana tetapi hanya beberapa rencana yang telah dijalankan sesuai dengan peraturan yang telah ditetapkan.

\section{REFERENSI}

Kun Dwi Apriliawati, Ekawati, B. K. (2017). Efektivitas Pelaksanaan Manajemen Organisasi Keselamatan dan Kesehatan Kerja Rumah Sakit (K3RS) Di Rumah Sakit X Semarang. Jurnal Kesehatan Masyarakat, 5, 2356-3346.

Kurniawan, R. Amelia. (2017).Identifikasi Potensi Bahaya dan Penilaian Risiko Pada Pekerja Ojek Sampan Tradisional di Pangkalan Brandan Tahun 2017 (Skripsi) . Ilmu Kesehatan 
Masyarakat. Universitas Sari Mutiara Indonesia: Medan.

Mailani K S (2016).Penerapan Standar Kesehatan Dan Keselamatan Kerja Di Rumah Sakit H. Adam Malik Medan tahun 2014-2015 (Tesis).S2 Ilmu Kesehatan Masyarakat. Universitas Sumatera Utara Medan.

Notoatmodjo, S. (2010). Metodologi Penelitian Kesehatan Edisi Revisi. Jakarta: Rineka Cipta. Nurpitriani, S. (2013). Penerapan Standar Kesehatan dan Keselamatan Kerja Rumah Sakit (K3RS) RSUD Ajappannge Soppeng (Skripsi).Fakultas Kesehatan Masyarakat. Universitas Hasanuddin Makassar.

Ramli, Soehatman. (2010). Sistem Manajemen Keselamatan dan Kesehatan Kerja OHSAS 18001. Jakarta: PT Dian Rakyat.

Republik Indonesia Kemenkes No.432 (2007).Pedoman Manajemen Keselamatan Dan Kesehatan Kerja (K3) Di Rumah Sakit. Menteri Kesehatan RI. Jakarta.

Republik Indonesia Permenaker No. 26. (2014). Penyelenggaraan Penilaian Penerapan Sistem Manajemen Keselamatan Dan Kesehatan Kerja. Berita Negara RI Tahun 2014. Nomor 2031. Menteri Ketenagakerjaan RI. Jakarta.

Republik Indonesia Undang-Undang No. 36. (2014). Kesehatan. Lembaran Negara RI Tahun 2014. Nomor 298. Presiden RI. Jakarta.

Republik Indonesia Permenakes No. 66. (2016). Keselamatan dan Kesehatan Kerja Rumah Sakit (K3RS). Berita Negara RI Tahun 2017. Nomor 38. Menteri Kesehatan RI. Jakarta.

Salmawati, L. dkk (2015).Hubungan Penerapan Sistem Manajemen Keselamatan Dan Kesehatan Kerja Dengan Motivasi Kerja Dan Stres Kerja Pada Perawat Di Rumah Sakit Umum Anutapura Palu. Jurnal Manajemen Pelayanan Kesehatan 18(1), 46.Universitas Tadulako Palu.

Sucipto, D. C. (2014).Keselamatan Dan Kesehatan Kerja. Yogyakarta: Gosyeng Publisher.

Sunandar, Ibrahim. H, Damayanti,S.D, A.(2017). Gambaran Penerapan Standart Keselamatan dan Kesehatan Kerja Rumah Sakit Umum Daerah Haji Makassar, Public Health Science Journal, 9(2), 160-173. Universitas Islam Negeri Alauddin Makassar.

Toding Ryane, Jootje M.L. Umboh, J. J. (2016). Analisis Penerapan Sistem Manajemen Kesehatan Dan Keselamatan Kerja ( Smk3 ) Di Rsia Kasih Ibu Manado. Jurnal Ilmiah Farmasi, 5(1), 284-289.

Triwibowo, cecep. (2013).Kesehatan Lingkungan dan K3. cetakan I. Yogyakarta: Nuha Medika

Yusuf, M.A . (2017).Metode Penelitian Kuantitatif, Kualitatif \& Penelitian Gabungan. edisi I. Jakarta: PT Fajar Interpratama Mandiri. 